\title{
INCOME AND EXPENDITURE PATTERN OF SHG AND NON SHG RURAL HOUSEHOLDS OF TELANGANA
}

\author{
J. SHIRISHA, K. UMA DEVI \& S. SUCHIRITHA DEVI \\ Department of Foods and Nutrition, College of Home Science, Professor Jayashankar
}

Telangana State Agricultural University, Hyderabad, India

\begin{abstract}
A major objective of the SHGs (Self Help Groups) is to alleviate poverty, by extending banking services to the poor, thereby helping them to enhance employment and income opportunities to come out of poverty. Geeta Manmohan et al., (2008) views that, Micro finance is such a tool, which directly hits the poverty by helping poor or enabling them not only to survive, but also to improve their standard of living. SHGs reduce poverty and vulnerability of the poor by increasing capital / asset formation at the household level, improving household and enterprise incomes, enhancing the capacity of individuals and households to manage risk (Swamy and Tulasimala 2013). The study was carried out in Dokur and Aurepalle villages of Mahaboobnagar, with the aim to compare the SHG household and Non SHG households in terms of socio economic conditions. Sixty SHG households and 15 Non SHG households were selected from each of the two villages, forming a total of 120 SHG and 30 Non SHG households. The income and expenditure of the selected SHG and Non SHG households were obtained, through a structured schedule. The data indicated that, in the high income category SHG were more in number, whereas $27 \%$ of each fell in the middle and $34 \%$ and $43 \%$ of SHG and Non SHG were in low income per annum. Non SHG households were spent high income on food than the SHG, whereas expenditure on health was higher for the SHG, than the Non SHG. The expenditure pattern for clothing and children's education were same for the SHG and Non SHG households. Policy-makers and program implementers must act today, to fulfil the gap and enhance the program results in all over the country, as program has fast and positive effect in changing the society.

KEY WORDS: Household, Income, Non SHG, SHGs, Poor, Women Empowerment, Decision Making, Children's Education \& Expenditure Pattern
\end{abstract}

Received: Aug 12, 2017; Accepted: Aug 31, 2017; Published: Sep 27, 2017; Paper Id.: IJEEFUSOCT20173

\section{INTRODUCTION}

The small beginning of linking only 500 SHGs to banks in 1992, had grown to over 0.5 million SHGs by March 2002, and further to 8 million SHGs by March 2012, according to a report by NABARD. In the southern states, almost 100 percent of the SHGs linked to banks in the pilot stage, while the total number of SHGs linked in southern states shrank to 46 percent, by March 2012 (Archana Kumari, 2013).

Poor families living below the poverty line were then organized into SHGs, established with a mixture of government subsidy and credit from investment banks. The main aim of these SHGs, is to focus on income generation and raising poor families above the poverty line. The SHGs are supported and trained by nongovernment organizations (NGOs), community based organizations (CBOs), individuals, banks self-help promoting institutions, and microfinance institutions (MFI). The most prominent models of delivery for 
microfinance in India, continue to be SHGs, promoted by the state governments, NGOs, a few regional, rural banks, and specialized MFIs, that use various models to make both group and individual loans. The southern states of India, experienced the largest concentration of SHG activities, both with state support, and promoted by private MFIs (Saha et al., 2013).

Women constitute a major part of beneficiaries of micro-finance activities in India. It helps women to gain control over the means of living and lift themselves out of poverty and vulnerability. By saving one rupee per day per head, they themselves evolve as the driving force and borrow from their savings and invest in their family with the income they generate through this microfinance. It helps women to achieve economic and political empowerment, within their homes, their villages and their countries. Since, many of the studies have shown the positive impacts of SHG's on aspects like women empowerment, decision making, self confidence, increased availability of assets, entrepreneurial skills, loan repayment and utilization. One needs a good nutritional status, to perform their fullest potential by using best of their resources. Many of the government programs are targeting women of SHG, due to easy mobilization. So, the present study was aimed, to evaluate the income and expenditure pattern among SHG and Non SHG Households.

\section{METHODOLOGY}

The study was carried out in Dokur and Aurepalle villages of Mahboobnagar, with the aim to compare the SHG household and Non SHG households, in terms of socio economic conditions. Sixty SHG households and 15 Non SHG households were selected from each of the two villages, forming a total of 120 SHG and 30 Non SHG households. The income and expenditure of the selected SHG and Non SHG households, were obtained through a structured schedule.

\section{RESULTS AND DISCUSSIONS}

Based on the annual income, the households were grouped into three categories of income and the distribution of SHG and Non SHG is given in table 1.

Nearly $34 \%$ of SHG and $43 \%$ Non SHG, belonged to low income group with an income of Rs.20, 000/- to Rs.60, 000/- per annum. While 27\% each of SHG and Non SHG were in the middle income category, with Rs.60, 000 to Rs.1, $00,000 /-, 39 \%$ of SHG and $30 \%$ of Non SHGs were in high income category, with earnings $\geq$ Rs. $1,00,000 /-$. Though the difference is less between SHG and Non SHG Households, the results were supported by Anila (2012) that, self help groups in the study area increased the income level of the respondents nearby, 16 percent respondents were in the income group of $1000-1500$, before joining the scheme, but that percentage has increased to 18.83 , after joining the group. The percentage of respondents of the income group, 1500-2500 have been 35 before joining the scheme. It has increased to 36.67, after joining the group.

Table 1: Income Status of SHG and Non-SHG Households

\begin{tabular}{|c|c|c|c|c|}
\hline Description & \multicolumn{2}{|c|}{$\begin{array}{c}\text { SHG Houses } \\
(\mathbf{n = 1 2 0})\end{array}$} & \multicolumn{2}{c|}{$\begin{array}{c}\text { Non-SHG Houses } \\
(\mathbf{n = 3 0})\end{array}$} \\
\hline & $\mathbf{N}$ & $\mathbf{\%}$ & $\mathbf{N}$ & $\mathbf{\%}$ \\
\hline Household annual income & & & & \\
\hline Rs.20,000-60,000/- & 41 & 34 & 13 & 43 \\
\hline Rs.60,000-1,00,000/- & 32 & 27 & 8 & 27 \\
\hline Rs. $\geq 1,00,000 /-$ & 47 & 39 & 9 & 30 \\
\hline
\end{tabular}

The findings did not, however, find increases in income or assets, but interestingly, the effects were not limited to, 
group members, indicating spill-over effects for communities in which SHGs were formed (Deininger and Liu, 2009).

Expenditure on food, children's education, clothing and health was given in table 2. For food $30 \%$ of the households were spending 10,000 to 30,000/- among SHGs where as $40 \%$ for Non SHGs followed by $66 \%$ of SHGs and $50 \%$ Non SHGs households were spending 30,000/- to 60,000/- and 4\% SHGs and 10\% Non SHG households spent above $60,000 /$ - annually.

Similarly, on children's education, 79\% of the SHG and 77\% Non SHGs spent under 5,00/-, 13\% households of SHGs and 10\% Non SHGs were spending 5,00 to 10,000/- and 8\% of the SHG and $13 \%$ Non SHG households spent above 10,000 /- for a year. Clot Seventy six percent SHG and 80\% Non SHGs households spent 1,000 to 5,000/-, 22\% of the SHG and $17 \%$ Non SHG households spent 5,000 to 10,000/- and 2\% of the SHG households and 3\% Non SHGs were spent above 10,000/-.

Table 2: Expenditure Pattern of SHG and Non SHG Households

\begin{tabular}{|c|c|c|c|c|}
\hline \multirow[t]{2}{*}{ Description } & \multicolumn{2}{|c|}{$\begin{array}{c}\text { SHG Households } \\
(n=120)\end{array}$} & \multicolumn{2}{|c|}{$\begin{array}{c}\text { Non-SHG Households } \\
(\mathbf{n}=\mathbf{3 0})\end{array}$} \\
\hline & $\mathbf{N}$ & $\%$ & $\mathbf{N}$ & $\%$ \\
\hline \multicolumn{5}{|l|}{ Expenditure on food (Yearly) } \\
\hline $10,000-30,000$ (Rs.) & 36 & 30 & 12 & 40 \\
\hline 30,000-60,000(Rs.) & 79 & 66 & 15 & 50 \\
\hline 60,000 and above(Rs.) & 5 & 4 & 3 & 10 \\
\hline \multicolumn{5}{|c|}{ Expenditure on education(Yearly) } \\
\hline 0-500(Rs.) & 95 & 79 & 23 & 77 \\
\hline 500-10000(Rs.) & 15 & 13 & 3 & 10 \\
\hline Above 10000(Rs.) & 10 & 8 & 4 & 13 \\
\hline \multicolumn{5}{|c|}{ Expenditure on clothing(Yearly) } \\
\hline $1000-5000($ Rs. $)$ & 91 & 76 & 24 & 80 \\
\hline 5000-10000(Rs.) & 26 & 22 & 5 & 17 \\
\hline Above 10000(Rs.) & 3 & 2 & 1 & 3 \\
\hline \multicolumn{5}{|l|}{ Expenditure on health(Yearly) } \\
\hline 1000-5000(Rs.) & 111 & 92 & 26 & 87 \\
\hline $5000-10000(\mathrm{Rs})$ & 8 & 7 & 3 & 10 \\
\hline Above 10000(Rs.) & 1 & 1 & 1 & 3 \\
\hline
\end{tabular}

While $92 \%$ of SHG and $87 \%$ Non SHG households were spending 1,000/- to 5,000/- on health, similarly $7 \%$ and $10 \%$ of SHG and Non SHG households were spending 5,000 to 10,000/- and, 1\% and 3\% of SHG and Non SHGs were spent above 1,00,000/- for health care facilities, annually.

Increased levels of employment and income of SHG households, are expected to raise their expenditure on various items. The level and growth rate of annual household expenditure on food and non-food items, are reported by several authors. While, the expenditure on food included cereals, pulses, edible oils, vegetables, milk, and milk products, meat and fish, sugar, gur, and other items, the expenditure on non-food included clothing, footwear, consumer durables, pan, beedi \& cigarettes, intoxicants, ceremonies, newspaper, travel and also on education and health (Ghosh 2012).

The data indicated Non SHG households were spent high income on food than the SHG, where as expenditure on health was higher for the SHG than the Non SHG. The expenditure pattern for clothing and children's education were same, for the SHG and Non SHG households.

Anuppalle and Reddy (2008), observed the improvement in health conditions of the rural women, after joining in the SHGs was more in India, in particular at Andhra Pradesh compared to the other countries like Africa and Indonesia. 
The results were partially correlated with the results of Swamy V and Tulasimala BK (2013) reported that, the mean family non-food expenses have increased from Rs. 3596 in pre-SHG situation, to Rs. 6228 after SHG impact, registering an improvement to the extent of $73.24 \%$.

The nutritional status of adult men and women, was significantly associated with the religion, community, type of house, type of family, occupation of the head of the household, literacy status, monthly per capita income, land holding, electrification, source of drinking water, sanitary latrine, type of cooking fuel, morbidity and family size. The prevalence of overweight/obesity was significantly high, among the pucca house residents, joint families or extended nuclear families, higher monthly per capita income, engaged in business and service, land lords, large farmers, presence of electricity, sanitary latrines and HHs using LPG for cooking purposes (NNMB, 2012).

\section{CONCLUSIONS}

The Self Help Groups (SHG) were used by the government, NGOs and others worldwide empower women, and to give lives to the poor families. SHGs are not treated as financial system, but they are formed with a view to social and economic change of the rural people, especially for the rural women. The SHG program clearly plays a central role in the lives of the poor. The program in various blocks, all seems to be very successful in reaching poor clients. Importantly; there is evidence of increased household income. Program loans are one of the main ways, clients overcome food insecurity with sickness, disease, emergencies and crises, where program participants seem to transfer the loan source from friends and money lenders to SHG loans, to meet these expenses. The fruitfulness of the program results was not distributed evenly. Policy-makers and program implementers must act today, to fulfil the gap and enhance the program results and overcome the poverty.

\section{REFERENCES}

1. Anila, A.A, 2012. A Study on Socio-Economic Condition of Self Help Group Members in Tirunelveli District, Tamil Nadu. International Journal of Business Economics \& Management Research. 2(2): 216-224.

2. Anuppalle and Reddy, R. 2008. Self-help groups in India - A catalyst for women economic empowerment and poverty eradication. 33rd Global conference of ICSW, tours (France). June 30th - July 4th.

3. Archana, K. 2013. Empowerment unto the last. Kurukshetra. 61(9):15-16.

4. Deininger, K and Liu, Y. 2009. Policy research working paper on Economic and Social Impacts of Self-Help Groups in India. The World Bank publications.

5. Geeta, M., Monika and Sumita. 2008. Rural Banking and Micro finance. Southern Economist. 47(2): 9-12.

6. Ghosh, M. 2012. Micro-Finance and Rural Poverty in India Shg-Bank Linkage Programme. Journal of Rural Development. $31(3): 347-363$.

7. National Nutrition Monitoring Bureau. 2012. Diet and Nutritional status of rural population, prevalence of hypertension and diabetes among adults and infants and young child feeding practices- report of third repeat survey. National Institute of Nutrition, Indian Council of Medical Research, Hyderabad.

8. Saha, S., Annear P.L and Pathak, S. 2013. The effect of Self-Help Groups on access to maternal health services: evidence from rural India. International Journal for Equity in Health. 12: 36.

9. Swamy, V and Tulasimala, B.K. 2013. Does microfinance impact on food security and living standard of the poor?. Journal of Business Economics and Management. 1(5): 69-81. 